\title{
En torno al proceso de caracterización barroca del retablo toledano del siglo XVII
}

\author{
Antonio José DíAz FernÁNDEZ \\ Universidad Nacional de Educación a Distancia \\ Departamento de Historia del Arte \\ ajdiaz@jccm.es
}

Recibido: 01-03-2012

Aceptado: 05-10-2012

\section{RESUMEN}

Con este trabajo se trata de situar el momento en el que el retablo toledano de mediados del siglo XVII adopta las características tipológicas y formales del retablo barroco madrileño, cambio que personaliza el arquitecto Juan Gómez Lobo constituyendo un arte bien definido del que es exponente el retablo de Ntra. Sra. de la Esperanza de la iglesia de San Lucas, ejemplo de la normalización barroca del retablo en Toledo en la década de los sesenta.

Palabras clave: arte barroco, barroco toledano, barroco madrileño, retablos del s. XVII, Juan Gómez Lobo, retablo de Ntra. Sra. de la Esperanza.

\section{Around the Process of Baroque Characterization of Toledan Altarpiece in XVII ${ }^{\text {th }}$ Century}

\begin{abstract}
With this work is to put the time in which the toledan altarpiece of mediated of the XVIIth century adopts the typological features and formal of the baroque altarpiece of Madrid, a change than customs the architect Juan Gómez Lobo constituting a well-defined art of which is exponent the altarpiece of Ntra. Sra. de la Esperanza in the church of San Lucas, an example the baroque standardization of the altarpiece in Toledo in the sixties.
\end{abstract}

Key words: Baroque Art, Baroque Toledan, Baroque Madrilenian, Altarpieces of XVII ${ }^{\text {th }}$ Century, Juan Gómez Lobo, Altarpiece of Ntra. Sra. de la Esperanza. 
El laborioso estudio del retablo barroco en Toledo nos ha conducido, entre otras, a ciertas consideraciones sobre la aparición de los modelos de la arquitectura decorativa de gestación predominantemente madrileña y la paulatina retirada de los planteos que los arquitectos de retablos toledanos habían heredado del clasicismo acuñado en la ciudad desde principios del siglo XVII, y extendido hasta prácticamente sus años centrales. Y contra este continuismo, la necesaria evolución estilística parecía no haberse resuelto en favor de un verdadero arte barroco del retablo en Toledo, en tanto que no se había tenido el suficiente conocimiento sobre este tipo de obras artísticas en madera y destinadas para la elocuencia de la imagen religiosa y el decoro de las iglesias en el nuevo contexto cultural y contrarreformístico del siglo XVII ${ }^{1}$.

Durante ese periodo precedente, nombres acreditados por su titulación y cargos al frente de las obras catedralicias como Nicolás de Vergara el Mozo (†1606), Juan Bautista Monegro (†1621) y su discípulo Toribio González de la Sierra (†1625) se afirman en el purismo arquitectónico, en cuyo declinar se desenvuelven tardíamente Juan Manuel Theotocópuli (†1632), Juan Fernández (†1639) y Lorenzo Fernández Salazar ( $\dagger 1643$ ) como arquitectos post-herrerianos ${ }^{2}$; todos identificados con la pervivencia de los postulados clasicistas aplicados también, por natural derivación conceptual, a una arquitectura de retablos, de estructura mayormente desornamentada aunque con cierto valor decorativo, impulsada principalmente por Monegro y a la que se contraponían a veces rasgos del manierismo de El Greco (†1614), discutibles en su originalidad, pues su pretendido antiherrerianismo pudo haber coincidido con las tendencias locales basadas en el mismo clasicismo corrector, poniéndose en duda la propia característica formal del agrupamiento de columnas corintias que habrá de cultivarse en adelante en retablos de factura toledana ${ }^{3}$.

Partiendo de otra generación de arquitectos y ensambladores que sitúan su actividad madura en torno a los años cuarenta de la centuria (citemos principalmente a Juan García de San Pedro, su discípulo Alonso García Becerro, José de Ortega y Juan Muñoz de Villegas), el retablo toledano se orienta con las lógicas vacilaciones del cambio hacia estructuras de mayor unidad compositiva experimentando sobre obras de porte mediano, generalmente retablos tetrástilos de dos cuerpos, que admiten graduales cambios en su articulación y una renovación en su ornato sin todavía desprenderse de fórmulas anteriores, aunque fijando un retablo tipo de orden corintio o compuesto, en razón del juego pictórico de sus capiteles y friso. Desde esta perspectiva, las experiencias monegrinas habrían abocado a una arquitectura barroca clasicista, dentro de un lenguaje acorde con la autoridad y representatividad del mayor comitente, la Iglesia; que desde el punto de vista constructivo, está abierta a la búsqueda

1 Estas investigaciones conforman nuestra tesis doctoral intitulada El retablo barroco en Toledo (16321732), dirigida por D. Víctor NIETO ALCAIDE y presentada en la Facultal de Geografía e Historia de la UNED, mayo de 2012 (inédita); y a través de la que se propone una base bibliográfica sobre el análisis de la realidad de un medio artístico fecundo en producciones retablísticas, que aquí se relacionan, y la existencia de una amplia nómina de artistas representativos de las distintas fases estilísticas del periodo tratado. Las fotografías aquí mostradas se deben a Renata TAKKENBERG-KROHN (excepto figs. 4 y 5 ).

2 MARÍAS (1983-1985) I pp. 189-192 y II pp. 205-207 y 212.

3 Es la hipótesis de Marías respecto al controvertido retablo mayor de la capilla de San José en Toledo, tal vez reformulado por Monegro, vid. Marías (1977) p. 326; Idem (1983-1985) II pp. 115-116. MARTÍN GONZÁLEZ (1993) pp. 40-41. 


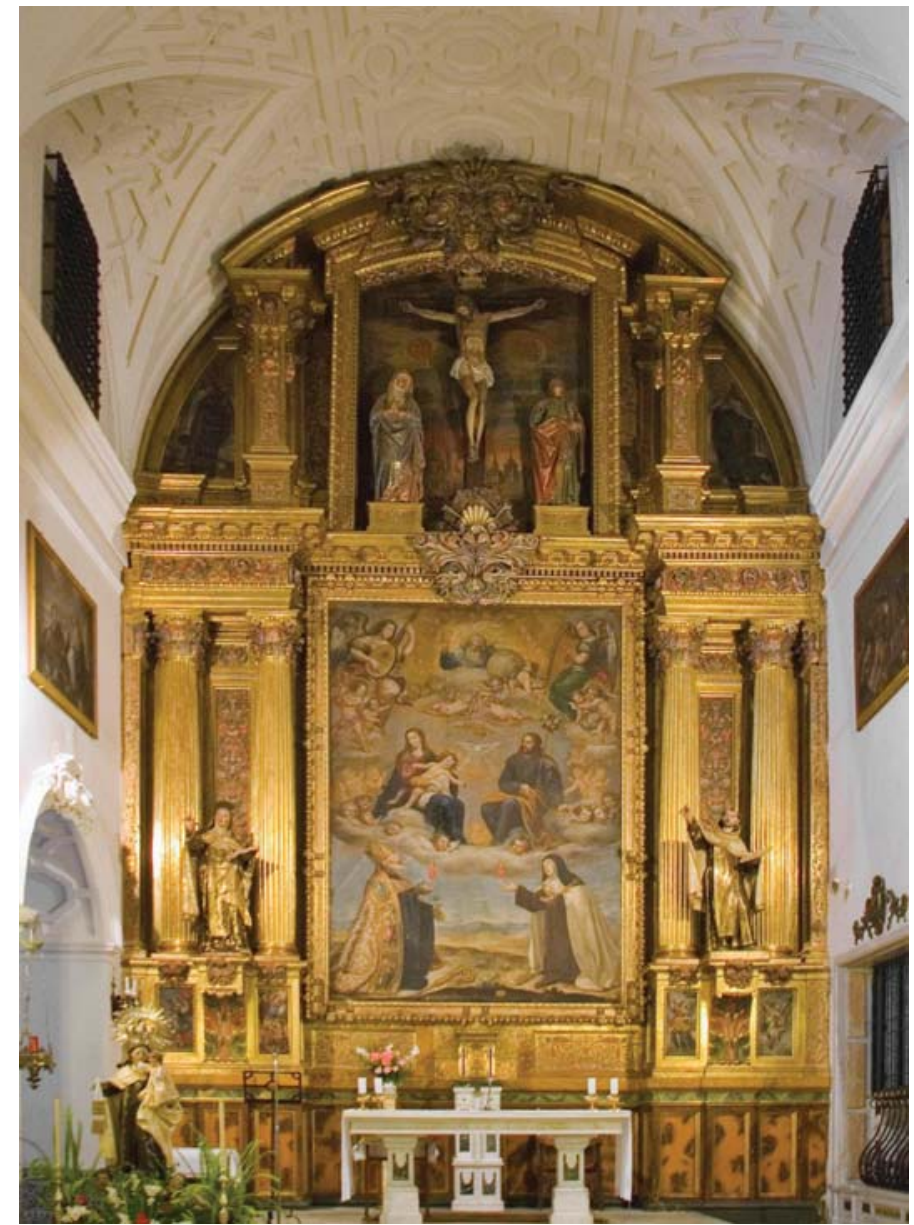

Fig. 1: Toledo. Iglesia de carmelitas descalzas de San José. Retablo mayor, de Alonso García Becerro.

de la plasticidad y el claroscuro de las superficies en alzados interiores de los templos y hacia la consecución de espacios orgánicos, como apunta Suárez Quevedo ${ }^{4}$; con lo que esta predisposición suponía para que el incipiente retablo barroco toledano tendiese a su acomodación intelectual con nuevos diseños y renovadas propuestas.

Ahora bien, aunque dentro de este contexto recurrente, no deja de alzarse en Toledo una obra pionera del nuevo concepto que se está gestando inicialmente en retablos de la capital madrileña, en la línea de creación orientada por el jesuita Francisco Bautista y sus colaboradores inmediatos perfilando ya un estilo diferenciado ${ }^{5}$. Se trata del retablo mayor del monasterio de carmelitas descalzas de San José, trazado y obrado en 1641 por el maestro de arquitectura Alonso García Becerro (†1647), a quien se podría considerar como un virtual seguidor de Pedro de la Torre, sin que esta cercanía artística al arquitecto madrileño pueda estar mejor documentada ${ }^{6}$. Esta obra

4 SUÁREZ QUEVEDO (1990) pp. 105-106. Como cima de este barroco clasicista, la iglesia de las Capuchinas de Toledo, obra de Bartolomé Zombigo y Salcedo, de 1665-1671.

5 Su socio más cercano fue el arquitecto Pedro DE LA TORRE, vid. TOVAR (1973) pp. 267-268. La colaboración de ambos en el retablo mayor de la ermita de Ntra. Sra. de la Fuencisla de Segovia, en 1645, evidencia el carácter novedoso de un estilo ya maduro en esos años.

6 DÍAZ FERNÁNDEZ, Antonio José, "La influencia del barroco madrileño en Toledo: el retablo mayor de las carmelitas descalzas (1641) y su autor Alonso Garcia Becerro" (en prensa). 
es precursora del barroco en Toledo en cuanto recurre al retablo de orden gigante alzado por cuatro columnas corintias exentas, de singular capitel compuesto, que sirven de arquitectónico encuadre a la grandiosa tela enmarcada de San Agustín y Santa Teresa ofreciendo sus corazones flamantes a la Sagrada Familia y a la Trinidad presidida por Dios Padre, del pintor madrileño Antonio Pereda (1640), alojada en la ancha calle central, mientras que dos esculturas de Santa Teresa y San Juan de la Cruz se anteponen sobre repisas laterales a sus fustes pareados. A su vez, sobre un elegante cornisamiento viñolesco, el cerramiento en semicírculo ofrece un profundo ático entre machones con las caracterísiticos motivos manejados en el foco artístico de referencia: cabezas talladas en vez de capitel y festones de frutas; y bajo cuyo frontón se erige un Calvario de escultura, dejando pinturas en ambos lunetos ${ }^{7}$ (Fig. 1).

Ante este brote temprano de "madrileñismo", tanto en lo que a estructura unitaria se refiere como en la modalidad de retablo para pintura de gran formato, cabría una pronta reacción de adhesión hacia la nueva tendencia en el medio toledano que no se produce, pues esta transición se hará esperar en tanto que se suceden realizaciones de desigual naturaleza, representadas por el retablo mayor de la parroquia de San Cipriano, concebido en 1649-1650 por el ensamblador Juan García de San Pedro (†1668) como encargo de la influyente cofradía de Nuestra Señora, donde reinterpreta la organización en cuerpos y calles de retablos precedentes, alternado tableros para pinturas y hornacinas para esculturas, en razón de la advocación principal, Ntra. Sra. de la Esperanza, situada en la hornacina de medio punto del primer cuerpo, y del santo obispo titular del templo, situado en la caja central del segundo cuerpo ${ }^{8}$; y cuya fisonomía no puede ser más explícita de la resistencia a romper la superposición escurialense tan cara a los artistas formados a principios de la centuria pues, para el momento de su ejecución, se presenta como un epígono del recalcitrante herrerianismo toledano, contando con rasgos retardatarios no bien resueltos como un ático con columnas en

7 Policromado y dorado, sus adornos de cuño madrileño contrarrestan con las dos enormes tarjetas que jalonan el retablo, correspondientes ya a una redecoración de finales del siglo XVII. Con precedentes como el retablo mayor de la parroquial de Pinto (Madrid), de 1637, la referencia tipológica más inmediata podría ser el retablo del santuario de Begoña en Bilbao que planteó Pedro de la Torre en 1640.

8 ARCHIVO HISTÓRICO PROVINCIAL DE TOLEDO (AHPT), Protocolo 3457, fol. 412, escribano Diego Verde. Retablo que se contrató por dos veces. Tras el cabildo de 30 de mayo de 1649, la cofradía se afirmó en su intención "de haçer un Retablo y camarin para que su divina mag[esta] este con may[o]" decencia" y se nombraron a don Manuel Suárez de Mesa, Francisco de Cisneros, don Diego de Torres, Diego de Cañizares y Pedro García de Ayala, cofrades, mayordomos y escribano de la misma, para concertar la obra con el artista toledano Juan García de San Pedro en precio de 6.000 reales de vellón; bien que una vez hecho y asentado el retablo a mediados de 1650, el cura propio de la iglesia denunció la obra, por lo que la cofradía dio su poder en 9 de agosto de 1650 a los procuradores de causas José Rodríguez, Francisco Monje y Gregorio de Mesa para seguir el pleito ante el alcalde mayor de la ciudad "contra Juan garzia de ssanpedro m[aestr] ${ }^{\circ} \mathrm{de}$ arquitectura vez $[\mathrm{in}]^{\circ}$ desta ciudad ssobre los defectos de un Retablo que para el altar mayor de la dha yglessia por las $\mathrm{d}[\mathrm{ic}]$ has parttes fue encarg[a $] \mathrm{d}^{\circ}$ al $\mathrm{d}[\mathrm{ic}]$ ho maestro el qual no cumplio con la traza y condiziones". Una conciliación entre ambas partes permite en 18 de noviembre de 1650 volver a escriturar el encargo del ahora llamado "añadido y nueva obra", según trazas y condiciones dadas al efecto y un precio de 3.500 reales y con el plazo de un año para su terminación (ibidem, fol. 636). Por su parte, en 25 de agosto de 1650, García de San Pedro había otorgado su poder al procurador del Número de Toledo Alonso de Escobar para diligenciar el fin del litigio ante las justicias competentes (ibid. fol. 418). La hornacina de la Virgen fue desfondada al construirse luego el camarín en 1660 (AHPT, Pr. 253, fol. 364, José DE MOYA Y LOAISA). 


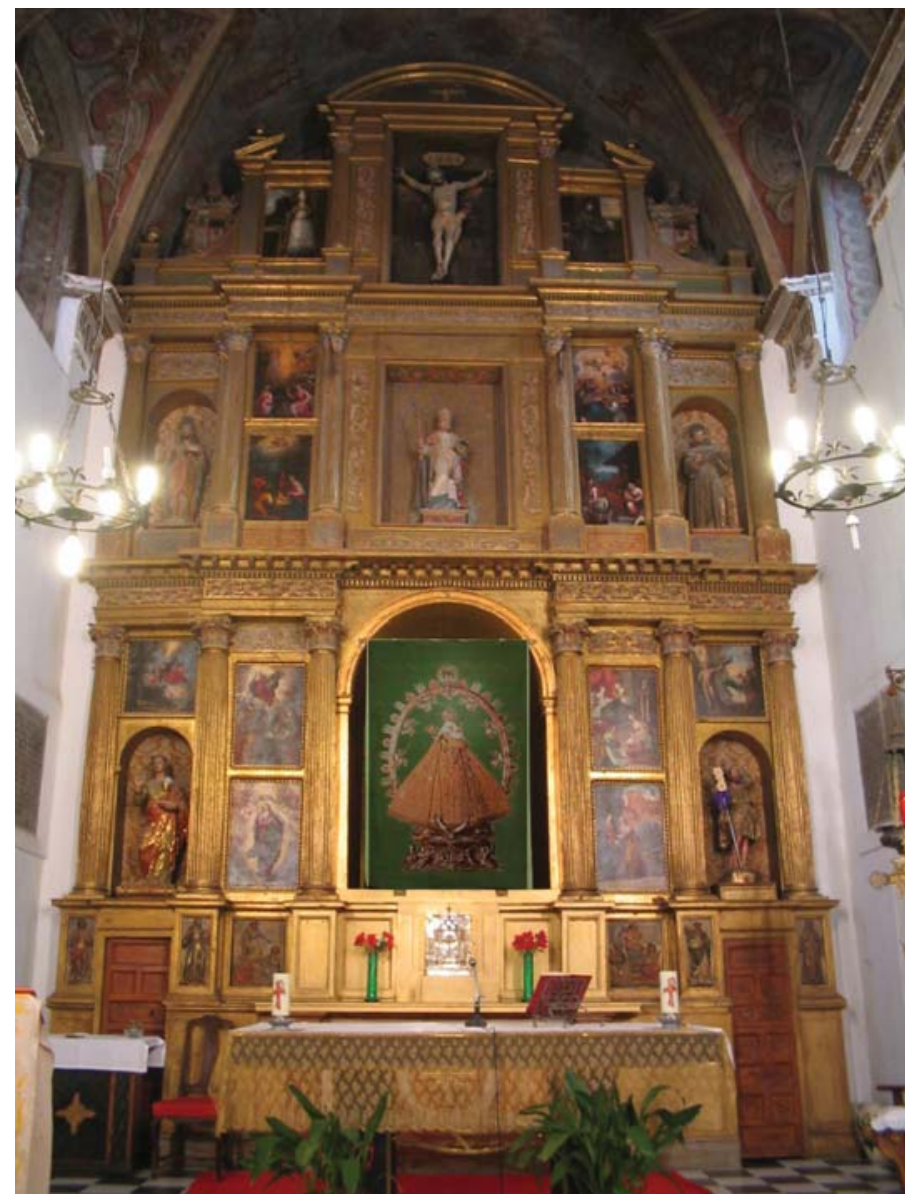

Fig. 2: Toledo. Iglesia parroquial de San Cipriano. Retablo mayor, de Juan García San Pedro.

vez de machones, o como los trozos de frontón de aire manierista que despuntan en los extremos superiores de las calles sobre marcos accesorios de pintura ${ }^{9}$ (Fig. 2 ).

Por el contrario, otras obras existentes en iglesias toledanas asumen una progresiva adaptación a nuevas propuestas, más ornamentales que estructurales, como sucede en el pequeño retablo dedicado a Ntra. Sra. de la Paz de la iglesia de la Compañía de Jesús (hoy parroquia de San Juan Bautista), realizado en 1656 por el arquitecto

9 Al igual que este retablo conservado, un retablo de similar concepción, pero desaparecido, fue el mayor de la iglesia parroquial de San Antolín y San Marcos de Toledo que el propio Juan García de San Pedro había proyectado a finales de 1647 , de tres cuerpos y tres calles, en una anticipación tipológica del retablo de San Cipriano, aunque con una clara función eucarística pues su primer cuerpo lo ocuparía el templete de la custodia. En favor del cura propio el Dr. D. Pedro González de las Cuentas, quien aplicaba el legado testamentario de doña Luisa de Pallás y Silva, el ensamblador se obligaba por el contrato escriturado luego en 30 de diciembre de 1647 , en precio de 10.500 reales de vellón y conforme «a las dichas condiciones y traça y modelo que esta echa y queda en poder del dicho $\mathrm{Ju}^{\circ}$ Garçia de san Pedro firmadas de el dicho señor Doctor [cura propio] y deel dicho $\mathrm{Ju}^{\circ}$ Garçia y deel presente scrivano» (AHPT, Pr. 3418, fol. 972, Eugenio F. de Valladolid). Ejecutado en parte el retablo, el "arquiteto" formalizaba una nueva obligación en 26 de mayo de 1653 para la realización de algunas mejoras que le permitirían ensanchar la calle central y la hornacina principal (AHPT, Pr. 3423, fol. 1121, Eugenio F. de Valladolid). Juan García de San Pedro otorgaba el finiquito de toda la obra en 27 de noviembre de 1657, al recibir del Dr. D. Fernando Ortiz, 527 reales del total ajustado (AHPT, Pr. 3427, fol. 1075, Eugenio F. de Valladolid). No obstante, este retablo fue nuevamente reformado y reestructurado a partir de 1664 por Juan Gómez Lobo. 


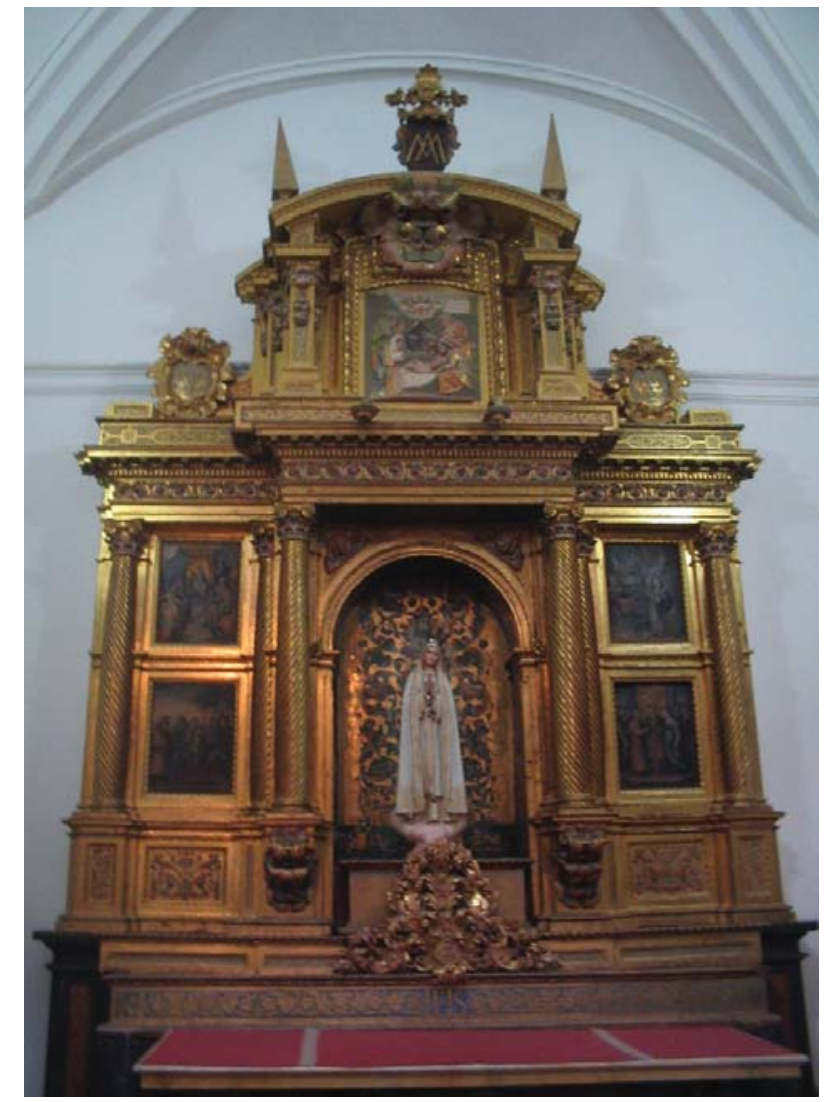

Fig. 3: Toledo. Iglesia parroquial de San Juan Bautista.

Antiguo retablo de Ntra. Sra. de la Paz, de Juan Muñoz de Villegas.

y ensamblador Juan Muñoz de Villegas $(† 1693){ }^{10}$. Aquí, pese a su estructura clasicista, aunque potenciada la calle central como portada adintelada con hornacina de medio punto, y pese a los llamativos fustes entorchados de las seis columnas y a la introducción de cuatro pinturas y un relieve pertenecientes al viejo retablo, otros elementos más novedosos se toman del repertorio foráneo. Lo son en lo decorativo las cartelas que transforman los pedestales centrales, y aún más las hojas y frutas talladas en las pilastras del potente ático construido entre machones escalonados, en el que no faltan las molduras acodilladas y se introduce la ya inconfundible tarjeta de hojas cartilaginosas bajo el frontón, la también llamada "hoja canesca" (Fig. 3). Ya en 25 de octubre 1647 en la misma iglesia jesuítica la congregación de la Inmaculada Concepción había encargado al ensamblador Juan García de San Pedro un retablo principal por iniciativa personal de don Pedro de la Mata Velasco, caballero de Santiago y Tesorero General del Real Consejo de las Indias ${ }^{11}$. Entregada la obra, comitente y artista renuncian a ella para replantear una nueva, siendo expedida después de su

10 AHPT, Pr. 3661, (1656) fol. 76, Francisco RODRÍGUEZ CORNEJO. También está documentado el contrato de dorado y estofado (de 25 de septiembre de 1664) por Antonio Gómez, maestro dorador y estofador, bajo condiciones redactadas por Bartolomé Zumbigo y Salcedo "arquitecto y ayuda de traçador mayor de las Rs. obras de su Magestad" (AHPT., Pr. 3176, s/f, Rodrigo de Hoz).

11 AHPT, Pr. 3418, fol. 571, Eugenio F. DE VALLADOLID. Poder de obligación otorgado por el artista a Diego Felipe de Velasco, Notario Público de la Audiencia Arzobispal de Madrid, que actuaría de fiador en el compromiso de obra. 


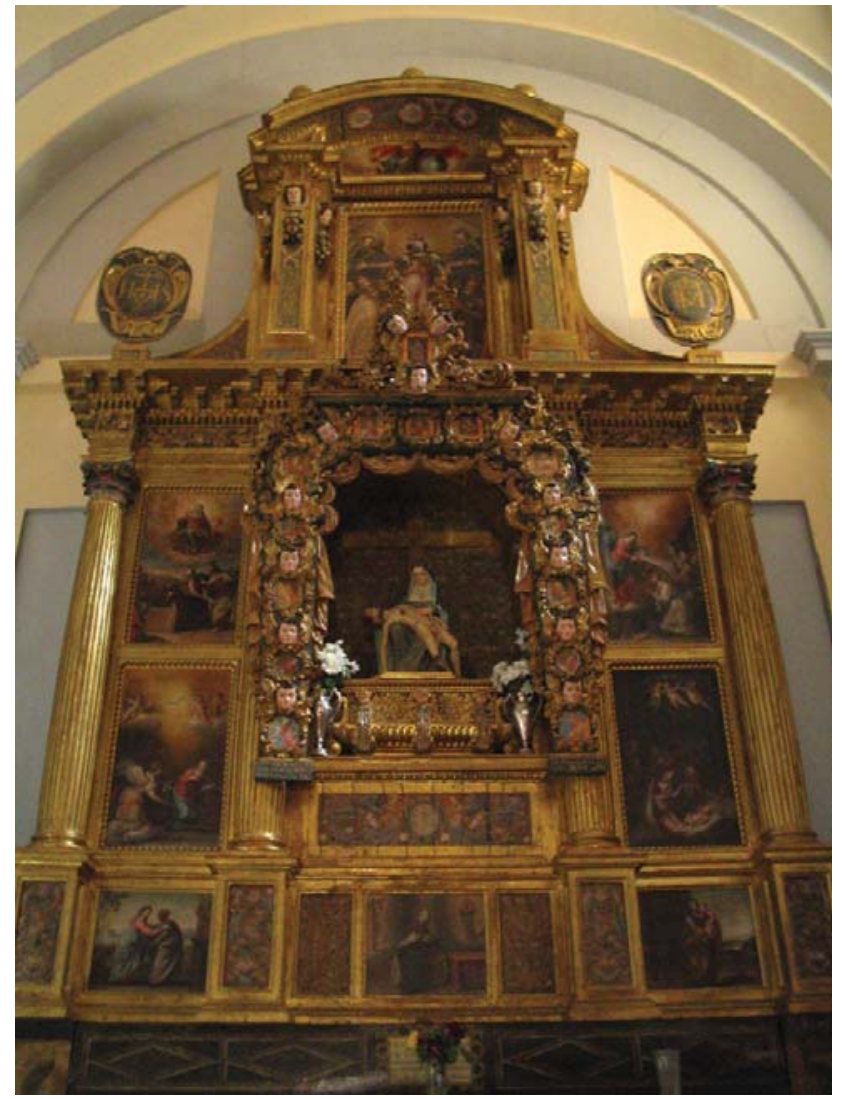

Fig. 4: Almorox (Toledo). Ermita de Ntra. Sra. de la Piedad. Retablo mayor, de Juan García San Pedro.

policromado a la ermita de Ntra. Sra. de la Piedad de Almorox (Toledo) ${ }^{12}$, donde hoy preside el altar mayor. Visto el retablo, en él se advierte la sintaxis del orden único en lo que es una aproximación al tipo de retablo de carácter unitario, predominando la hornacina central, si bien las calles laterales aún mantienen la división en dobles encuadres o tableros para cuatro pinturas, renunciando a las hornacinas para estatuas que tan insustituibles eran en la composición monegrina de muchos retablos tetrástilos, evidenciándose algo más de relevancia en los aditamentos de la talla a partir del orden corintio del entablamento y un ático entre machones con frontón curvo, todavía revestido a pincel y rematado por bolas escurialenses, pero que admite en los cajeados de las pilastras cabezas de querubes y festón de frutas naturalistas (Fig. 4). Rasgos que hubieron de mejorarse en el retablo definitivo contratado en 1652, y hoy desaparecido, con detalles que son fáciles de cotejar en las condiciones del contrato de dorado de 1656, en el que se alude a machones, tarjetas, cartelas de hojas, cabezas de serafines encarnadas, frutas estofadas y coloridas, follaje, etc. ${ }^{13}$.

12 AHPT, Pr. 3131, fol. 637, Rodrigo A. de Hoz.

13 La nueva escritura de contrato se firma en 22 de septiembre de 1652, para hacer "un rretablo para la sala de la congregaçion de nuestra señora de la conçeçion de la casa profesa de la conpañía de Jesus de esta çiudad conforme a la planta y traça que firmada de anbas partes de le a entregado a el dho Juan Garcia de san pedro para que lo ejecute", con distintas condiciones, en precio de 6.000 reales y acabado en el plazo de un año (AHPT, Pr. 136, fol. 263, Cristóbal CISNEROS). La obra de dorado y estofado se contrata en 18 de 


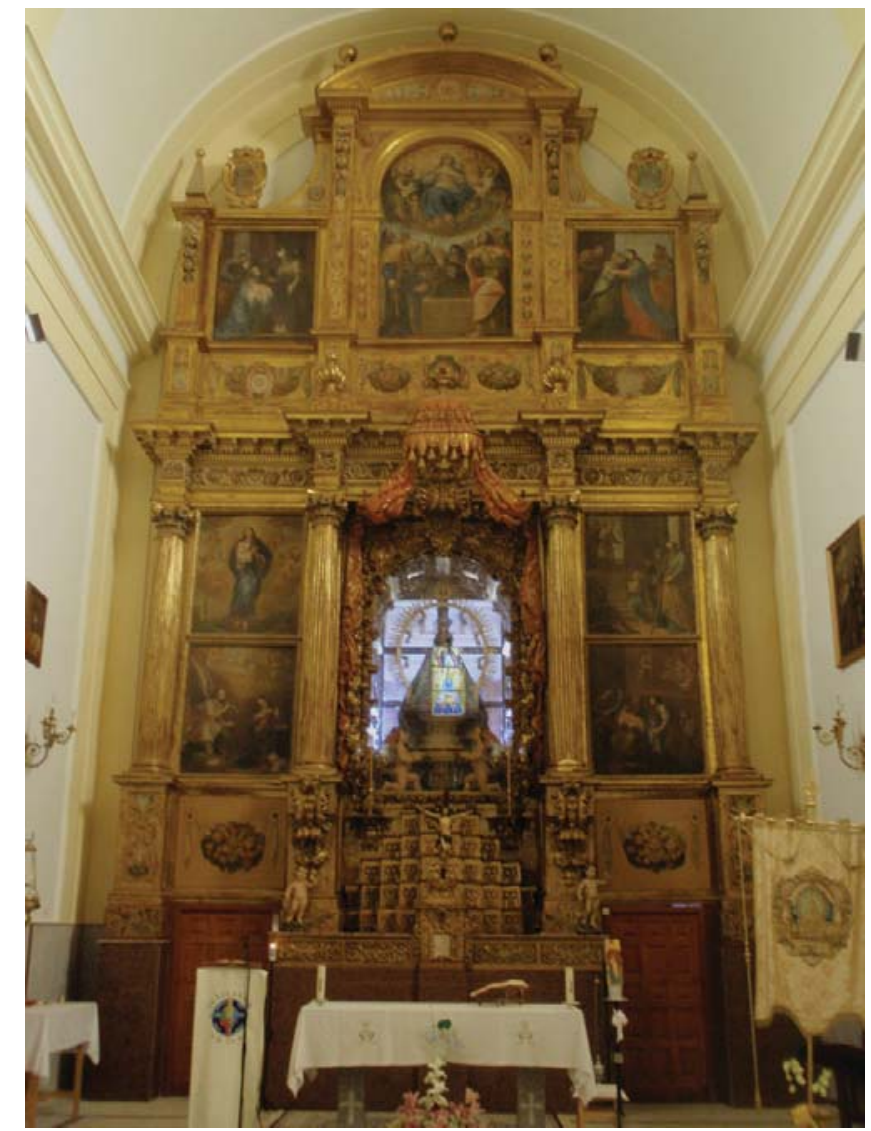

Fig. 5: Villa del Prado (Madrid). Ermita de Ntra. Sra. de la Poveda.

Retablo mayor, de José de Ortega.

Aunque tampoco se localice en la ciudad, a la producción toledana de estos años pertenece el retablo mayor del santuario de Ntra. Sra. de la Poveda de Villa del Prado (Madrid), que planteado en 1655 por el arquitecto José de Ortega $(\dagger 1673)$ realizaron sus socios Alonso de Ortega y Pedro Serrano, supeditado a siete lienzos de pintura y una hornacina principal con minúsculo camarín inserto en la caja, que luego sería horadado en el siglo XVIII abriéndolo en el transaltar ${ }^{14}$ (Fig. 5). El retablo posee las características de obra poco evolucionada en el orden estructural, pese al juego del entablamento sobre los soportes, y observada la solución en serliana del cuerpo superior y la templada utilización de adornos de talla sin interés efectista, algo consecuente con la formación clasicista de su autor. Sin embargo, tanto este retablo como el anterior ayudan a conocer el curso de los inevitables cambios que esperan a la retablística toledana de estos momentos ${ }^{15}$.

septiembre de 1656 por el pintor de Toledo Juan de Sierra en precio de 5.000 reales (AHPT, Pr. 3529, fol. 582, Nicolás LÓPEZ)

14 DÍAZ FERNÁNDEZ (2005) pp. 179-207. La calle central del retablo fue muy redecorada a principios del siglo XVIII con adornos ya churriguerescos al abrirse la capilla camarín.

15 García de San Pedro alcanzó a ser Maestro Mayor de obras de la Ciudad por acuerdo capitular de 6 de enero de 1651, en que «la çiudad nonbro por maestro mayor de las obras de Toledo a Juan Garçia de sanpedro veçino desta çiudad para q- asista y aga lo que la çiudad le ordenare y se le despache testimonio del nombramiento» (ARCHIVO MUNICPAL DE TOLEDO (AMT), Libro Actas Capitulares (1650), $\mathrm{n}^{\circ}$ 70, s/f.). José de Ortega ejerció de aparejador de maestros mayores catedralicios como Lorenzo Fernández de Salazar, Felipe Lázaro de Goiti y Cosme de Peñalacia, y asumió la maestría mayor de 1657 a 1671, como artista bien 
El tipo de retablo de características inequívocamente barrocas que hace su aparición en Toledo a mediados del siglo XVII ha de estar en la línea estilística que empieza a formalizar el ensamblador madrileño Pedro de la Torre desde 1630, tal vez el más conocido de los creadores y conformadores del género retablístico barroco, y en cuya génesis participa al mismo tiempo el arquitecto y pintor Sebastián de Herrera Barnuevo ${ }^{16}$. Pautas difundidas con firmeza por otros artistas del círculo cortesano como José de la Torre (†1664), Sebastián de Benavente (†1689) y Alonso García (de Dueñas) ${ }^{17}$. Si bien no son ajenas a la prefiguración del modelo las enseñanzas del granadino Alonso Cano, para algunos historiadores el verdadero innovador, más que en el uso de los órdenes arquitectónicos y su proporcionalidad, en la renovación del lenguaje ornamental aplicado a la arquitectura y, por supuesto, a la conformación de los retablos, siendo admiradas estas originalidades desde su presencia en la Corte en 1638 , y de las que se hicieron bien pronto eco los colegas madrileños, particularmente Herrera Barnuevo ${ }^{18}$.

En nuestro caso, el nuevo estilo se hubo de empezar a conocer y tantear por los artífices toledanos en los años de 1650 pero con más fuerza de asimilación en la década de los sesenta del siglo, años especialmente cruciales en la renovación a través del ineludible intercambio cultural entre la Villa y Corte de Madrid y una Ciudad Imperial aparentemente en decadencia, convertida más en una capital eclesiástica con ínfulas principescas por su alta condición de sede arzobispal y primada de las Españas y donde las grandes empresas artísticas centradas en la catedral eran confiadas plenamente a artistas madrileños por promotores de alcurnia como los arzobispos D. Baltasar Moscoso y Sandoval (1646-1666) y D. Pascual de Aragón (1666-1677). Así pues, el avance en las ideas tomadas del nuevo bagaje expuesto en proyectos y obras, por ser el referente más cercano para otras actuaciones artísticas en Toledo, se podría circunscribir en torno a una fecha inicial, la del año 1660, que coincide con la datación presumible del retablo principal de la capilla de Ntra. Sra. de la Esperanza de la iglesia mozárabe de San Lucas en Toledo. Ejemplar conservado con el que parece alcanzada la estabilización del retablo toledano en su caracterización plenamente barroca sin atadura alguna a los convencionalismos precedentes, pues de su autor Juan Gómez Lobo (ca. 1628-†1679), del que no se conoce documentalmente el taller donde hizo su aprendizaje, es oportuno considerar su formación ya en el ambiente cultural del momento, al pertenecer a una nueva generación de artistas toledanos sobre quien las influencias foráneas son más acusadas, erigiéndose en el necesario conformador del retablo en madera de concepción prechurrigueresca en Toledo.

instruido en los canónicos planteamientos de un fiel discípulo de Monegro como había sido su maestro y también retablista Toribio González de la Sierra, vid. SUÁREZ QUEVEDO (1990) p. 159.

16 Si Pedro de la Torre "acabó con los módulos del manierismo post-clásico y encaminó la arquitectura del retablo peninsular por los cauces internacionales del barroco", vid. TOVAR MARTíN (1973) p. 268, la facultad decorativa del pintor Herrera Barnuevo es igualmente importante en la evolución del barroco madrileño, vid. Díaz García (2010).

17 AGULLÓ Y COBO (1973) pp. 391-399.

18 RODRÍGUEZ G. DE CEBALLOS (1999) p. 258. Tras una breve estancia en 1634 en Madrid, es aceptada por todos como la primera etapa madrileña la de 1638 a 1652. Así, en 1643 optaba a la plaza vacante de Maestro Mayor de Obras de la Santa Iglesia Catedral de Toledo, sin éxito. En 1649 participaba en la decoración efímera para el recibimiento de la reina Mariana de Austria en Madrid. Y en 1650 Cano pasó a Toledo para comparecer particularmente en la obra del trono del Sagrario. 
En este sentido, habría que considerar algunos episodios previos de su actividad como el diseño y contratación en 1656 por este artista del retablo principal de la capilla de Ntra. Sra. del Buen Suceso o Consolación, de la iglesia parroquial de Santa María Magdalena, que en sus condiciones se había de someter a ciertas instrucciones comunicadas precisamente por Pedro de la Torre al tiempo de una de sus visitas a la ciudad ${ }^{19}$. Recomendaciones que nos son desconocidas y que tal vez incidieran en la concepción final, decorativa y funcional, de este gran retablo (al que poco después de construido se abrió camarín volado sobre la calle); obra retablística tan significativa que desaparecía en 1936 sin dejar mayor noticia de su aspecto que una vaga descripción que lo califica parcamente de «gran retablo corintio de dos cuerpos, en el primero de los cuales tiene colocadas la pequeña efigie de la Virgen de la Consolación, á quien la capilla está consagrada, y otras varias esculturas; y en el segundo, un lienzo que representa la Coronación de la Virgen» ${ }^{20}$. Ante su pérdida, quizás se pueda establecer en cierta medida su relación con el retablo dedicado a la Virgen que hay colocado en hornacina de la nave de la Epístola de la iglesia de Santa Leocadia, anónimo y de menor tamaño pero fechable en ese momento, cuyos rasgos tipológicos lo señalan como uno de los más armónicos y de más bellos efectos no obstante su sobriedad en la talla de molduras, compuesto de pedestal con pinturas y sagrario embebido y moldurado, un cuerpo principal de dos columnas corintias y estriadas, exentas, con la pecualiaridad de ser anichadas, acentuando el claroscuro, y que flanquean una hornacina avanzada y moldurada de medio punto en cuyo respaldo luce

19 AHPT, Pr. 3578, fol. 396, José MOYA LOAISA. De una parte, Juan Mateos y Pedro Carrasco Marín, mayordomos de la cofradía, y de la otra, Juan Gómez Lobo "maestro de escultor" vecino de Toledo, fiado por Alonso y Eugenio Lobo, que se obliga "conforme a la planta que tiene fecha y queda firmada de su nonbre y de los dichos mayordomos y del presente scrvn'..", y con las siguientes condiciones: 2/ "q- se an de guardar las enmiendas que Pedro de la torre Maestro de arquitecto tiene fechas y adbertidas al dicho $\mathrm{Ju}^{\circ}$ gomez lobo y constan por un papel firmado del dicho pedro de la torre que queda en poder del presente $\operatorname{ssn}^{\circ}$ juntamente con otras condiciones que por menor tiene fechas el dicho ju $\mathrm{u}^{\circ}$ gomez lobo en bista a la execucion de la planta que tanbien esta firmado de su nonbre sin que se entienda que estas condiciones ni las adbertencias fechas por el dho $P^{o}$ de la torre se contradigan en cosa alguna porque de todo ello se a de guardar y executar lo q- fuere mas conbeniente y mas realze para la ffabrica del dicho retablo y arquitestura"; 5/ "que estando acabado el dicho retablo y sentado en la dicha capilla lo a de ber el dicho $P^{o}$ de la torre $=\mathrm{u}$ otro qualquier maestro o maestros que se nonbraren por las partes para que declaren si a cumplido con las condicones y executado la dicha planta, donde no, lo a de enmendar a su costa en todo lo que ubiere faltado sigun la dicha planta esto en quanto a lo que constare por dichas declaraciones"; con el compromiso final de darlo enteramente acabado y asentado en su capilla en plazo de un año y medio y en precio de 15.500 reales de vellón. El retablo se doraba por Juan Molero de Alberca a partir de su contrato de febrero de 1664, al que asisten como testigos Bartolomé Zumbigo y Juan Gómez Lobo (AHPT, Pr. 255, fol. 74, José MOYA LOAISA). Bartolomé Zumbigo es quien dio las condiciones para la pintura del camarín a realizar por los pintores Simón Vicente y Diego Rodríguez Romano a partir de marzo de 1664 (ibidem, fol. 84).

20 PALAZUELOS (1984) II p. 1069. Otros datos indican que el cabildo de la cofradía de 28 de agosto de 1656 aprobó las trazas dadas por Gómez Lobo; trabajó las imágenes laterales de San Joaquín y Santa Ana el escultor [madrileño] Manuel Correas y el carpintero Juan de Herbias hizo la tarima del altar; en 1660, acabado de pagar el retablo con algunas demasías como el adorno de la suela del primer cuerpo y de los colgantes que se echaron a las columnas y después del dorado, estofado de imágenes y colocación de las pinturas en octubre de ese año, se hizo el traslado de la imagen; el retablo se desmontó durante la obra del camarín en 1662 y se terminó de dorar en 30 de octubre de 1664, y Gómez Lobo realizó otras pequeñas obras como el cerramiento y frontispicio de madera de la reja, vid. RAMÍREZ DE ARELLANO (1921) pp. 184-186. La decoración de camarín y capilla fue por cuenta del pintor toledano Simón Vicente, vid. REVENGA DOMÍNGUEZ (2002) pp. 303-304. 


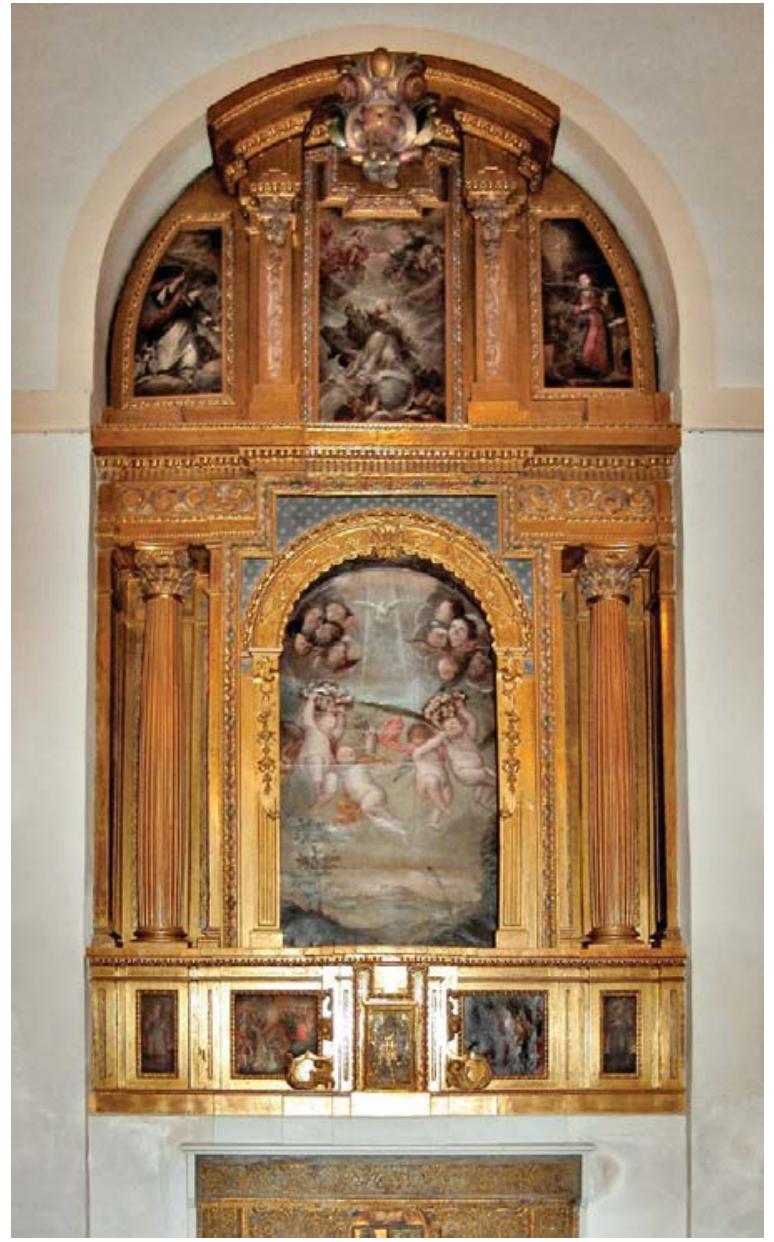

Fig. 6: Toledo. Iglesia parroquial de Santa Leocadia.

Retablo de Nuestra Señora, anónimo.

una gloria pintada con ángeles; y con friso de cogollos en un entablamento superado por cerramiento en vuelta redonda, comprendiendo ático entre machones cuyos tres sectores se cubren con sendas pinturas en lienzo, siendo las dos figuras de la escena de la Anunciación laterales al tema principal de la Glorificación de María, donde una tarjeta cactácea hace de broche en el frontispicio ${ }^{21}$ (Fig. 6).

En este punto, además de las trazas y maqueta del trono de la Virgen del Sagrario, expuesta en la catedral desde al menos el año $1654{ }^{22}$, los proyectos decorativos del Hermano Bautista y Pedro de la Torre para el revestimiento interior del Ochavo catedralicio hubieron de agudizar el sentido estético de Gómez Lobo, pues él era el encargado de tallar en madera y desde antes de 1662 los adornos de los relicarios, y que servirían de muestras para su vaciado en bronce ${ }^{23}$; motivos que se pueden reconocer

21 El retablo se dedicó a la Virgen de la Salud, luego cambió de advocación pues se reconoce por el inventario de 1785 «que fué de la Salud y ahora de los Remedios, con siete pinturas, dorado, de orden compuesto», vid. RAMÍREZ DE ARELLANO (1921) pp. 161 y 163.

22 NICOLAU (1996). En la difusión visual de esta obra destinada a ser un trono de plata, no sólo la propia maqueta sirvió de modelo, sino las numerosas estampas que ya desde 1647 empezaron a circular o las repetidas trazas y dibujos que copiaron para uso interno los artífices.

23 ZARCO DEL VALLE (1916) II p. 339. Todo bajo la supervisión del entonces maestro mayor José de Ortega, eran concretamente «adornos y targetas colgantes y festones de talla para un retablo que está sentado 
en las dos trazas de la sección interior de la suntuosa capilla, un octógono apilastrado con capiteles mixtos al estilo del Hermano Bautista, que guarda el archivo de Obra y Fábrica ${ }^{24}$. Fechadas en 1652, en sus detalles la una deja ver en el primer cuerpo tarjetas canescas en la clave de los ocho arcos de las hornacinas y en el segundo los marcos con orejetas de las ventanas con la alternancia de frontones, animados con pequeñas tarjetas en las claves y parejas de angelitos culminando, mientras que las pilastras de los ángulos se adornan con cartelas de cabezas de querubines de las que cuelgan festones de frutas. En el otro dibujo, más recargado, las tarjetas se agrandan entre arco y entablamento del cuerpo inferior, con un friso de modillones tupido de cogollos de gran relieve y donde el segundo cuerpo añade copiosas guirnaldas pendientes de los ventanales. Sin duda, la presencia periódica de Pedro de la Torre ya desde 1640 en Toledo sería prometedora en el ámbito artístico toledano a la hora de avivar la faceta decorativa de la arquitectura con nuevos motivos de notable carácter escultórico y efectista en tanto que la obra decorativa interior del Ochavo de las reliquias devenía en el mejor despliegue de arte barroco madrileño donde se integraba el espacio revestido con distintas calidades y placajes de mármoles, los brillantes bronces y ricos adornos que pautaban los ritmos compositivos de alzados y paramentos y como culminación la pintura ilusionista realizada desde 1665 por F. Rizi y J. Carreño en la cúpula y linterna.

Pero también advirtamos el desembarco en Toledo de dos obras de concepción madrileña. De un lado, el retablo secundario trazado por el mismo Pedro de la Torre para el hidalgo D. Gonzalo Hurtado en el convento de la Trinidad Calzada, contratado circunstancialmente con el retablista Juan García de San Pedro en 16 de agosto de 1652 en precio de 8.500 reales de vellón ${ }^{25}$. Y aunque posee los limitados recursos de un retablo menor de altar, sin embargo queda bien definido en su estilo y se afirma en su tipología barroca tan extraña entonces al medio local, cuanto más por su construcción novedosa de gran corporeidad arquitectónica, licencias compositivas y creación de efectos de claroscuro al contraponer masas y huecos, a lo que contribuye la configuración plástica de un reducido pero potente cuerpo superior entre machones y toda la estirpe de llamativas tarjas o macollas de hojas carnosas, marcadas molduras, cartelas en el friso y festones colgantes, bien característica del momento. En el otro extremo se hallaría por su tamaño el colosal retablo mayor del hospital de Tavera, como grandiosa empresa que habría de ejecutar entre 1657 y 1659 el ensamblador madrileño Juan de Ocaña y donde propiamente se introdujeron motivos de la rica decoración madrileña como modillones, subientes, tarjetas, marcos tallados en ángulos quebrados o acodillados, y otros elementos propios de talla, que la reforma dieciochesca de 1790 decidió suprimir, pero que en origen aportó una arquitectura de

en la capilla de las reliquias para baciallas de bronce». De nuevo, al año siguiente, el ensamblador declara tener hechas siete piezas de madera, colgantes y tarjetas que faltaban en el adorno del retablo principal del relicario y quiere que el maestro mayor lo ajuste e informe, lo cual hace José de Ortega en 3 de abril de 1663, con otro pago por un adorno y tarjeta para el nicho de la misma capilla (ibidem p. 340). Esta decoración fue transformada en el siglo XVIII.

24 FERNÁNDEZ y otros (2009) p. 144, dibujos no 52 y no 53: Sección del Ochavo. Pedro de la Torre. 1652; SUÁREZ QUEVEDO (1990) p. 257. MARÍAS (1999) pp. 295-305.

25 AHPT, Pr. 3404, fol. 459, ALONSO DE GALDO. DÍAZ FERNÁNDEZ, A. J., "El arquitecto madrileño Pedro de la Torre en Toledo y la identificación de un retablo de 1652" (en preparación). 
poderosa estructura en dos cuerpos de distinta altura y novedosa tipología constructiva en hornacina, por tratarse del primer retablo con cerramiento en cascarón alzado y visto en Toledo, ocupando la exedra abierta en el fondo del presbiterio ${ }^{26}$.

Con estos significados precedentes, el retablo toledano al que atribuimos la total asimilación del lenguaje barroco en Toledo se ubica, como hemos dicho, dentro de la iglesia de San Lucas en la capilla colateral de la Epístola bajo advocación mariana. Sobre su fecha, una imprecisa noticia lo relaciona con el ensamblador toledano Juan Gómez Lobo quien desde 1660 pudo haber contratado toda la talla, escultura y ensamblaje con el encargo de asentarlo después de acometer su dorado y estofado ${ }^{27}$. Ya avanzado el año de 1665 estaba acabado en blanco puesto que su policromado se adjudica al pintor Diego de Fuertes, que escritura en 18 de noviembre de ese año su dorado y estofado, y en cuyas condiciones se infiere el empeño por la calidad de la obra en las labores de aparejo, embolado, dorado y no menos en el estofado de sus jugosos pormenores de talla ${ }^{28}$. Ciertamente, el retablo resulta fastuoso pese a su regular estado de conservación, mostrando sus líneas arquitectónicas doradas

26 DÍAZ FERNÁNDEZ (2007) pp. 135-150. Fue escriturado en Toledo, en 29 de julio de 1657 y en precio de 60.000 reales. Ya Wethey advertía de su carácter barroco y extraño a la obra de Jorge Manuel, vid. Martín González (1993) p. 41.

27 RAMÍREZ DE ARELLANO (1921) p. 174. Sin precisar la autoría, se habla de una serie de limosnas de Gómez Lobo y de los pintores Simón Vicente y Nicolás de Latras, como cofrades de esta advocación, para hacer y contribuir a la decoración de toda la capilla y se añade que Gómez Lobo talló además dos ángeles grandes para el retablo y unas gradas molduradas, por lo que en 20 de noviembre de 1673 el cabildo de la cofradía le nombró su mayordomo. De poco interés para las guías locales, sin embargo, se cita con la Asunción en el centro y dos grandes lienzos a uno y otro lado, firmados por Miguel Vicente, vid. AINAUD DE LASARTE (1940) p. 32, lo que indicaría la existencia de dos lienzos en los intercolumnios colocados luego y hoy perdidos. Sin el documento de encargo, la contratación de la obra debió ser posterior a 1652 si tenemos en cuenta que el camarín era construido en 1651 por Lucas del Valle, maestro de obras de albañilería, que en 3 de enero se obligaba en favor de la cofradía titular a hacer «a las espaldas de nra $\mathrm{S}^{\mathrm{a}}$ un camarin del modelo traza y planta que esta echa» y acabando la obra con la yesería simple, dando de limosna 50 ducados (AHPT, Pr. 3374, fol. 4, DIEGO VOLANTE).

28 AHPT, Pr. 3595, fol. 1107, Jacinto SÁNCHEZ DE PRADO. Se toman las condiciones de una postura anterior (de 5 de octubre de ese año y en precio de 9.000 reales) presentada por el pintor José Risel, fiado por el propio Juan Gómez Lobo (ibidem, fol. 1103). Gómez Lobo recibía en el momento de la firma y en nombre del dorador los primeros 1.100 reales a cuenta de los 9.000 ajustados (ibidem, fol. 1136). Entre las partes a cubrir se menciona la sotobasa pintada en mármol de San Pablo con "todos los planiçios las molduras para que aRoje la dha piedra an de ser de oro linpio"; el banco principal dorado con "los cogollos y repisas de los netos coloridos de ermosa y barias colores como el arte lo pide"; y en su friso "un grabado". En cuanto a las imágenes, "los dos santos an de yr dorados y estofados de ermosa y ricas telas y brocado y se an de encarnar mate"; las columnas "de oro linpio sin escusar terçio ninguno porque se bea todos libres con sus capiteles y guebos estofados"; las pilastras, doradas, y en los vaciados "cogollos y brutescos a punta de pinçel y el canpo de oro linpio con capiteles coloridos"; los respaldos de los santos de oro limpio; "los cartones y fruteros que estan ençima de los dhos santos dorados y estofados y las frutas ymitadas al natural"; la moldura principal de oro limpio "porque ynporta para la autoridad de la obra= el carton questa sobre la dha moldura dorado y estofado con el campo de oro limpio"; la cornisa y arquitrabe de oro limplio con "los guebos estofados moguillones cogollos del friso y frutas de los dhos moguillones dorado y estofado colorido de ermosas colores sin que se encuentren y el canpo de los cogollos de oro linpio los guebos del paflon [sic] dorados y estofados y lo que resta de la cornisa de oro linpio para que aRoje la talla fuera"; las dos Virtudes, doradas y estofadas; los machones de oro limpio y "los tarjones y frutas que cuelgan doradas y estofadas"; la moldura segunda de oro limpio "para que salga la pintura"; "los cogollos de los costados dorados y estofados y el campo de oro linpio y el arco de ojas questa ençima de los dhos cogollos dorados y estofados y moldura de oro limpio"; "el tarjon ultimo dorado y estofado y el campo de oro linpio con el anjel encarnado mate= y el çerramiento todo en oro linpio con los guebos estofados". 


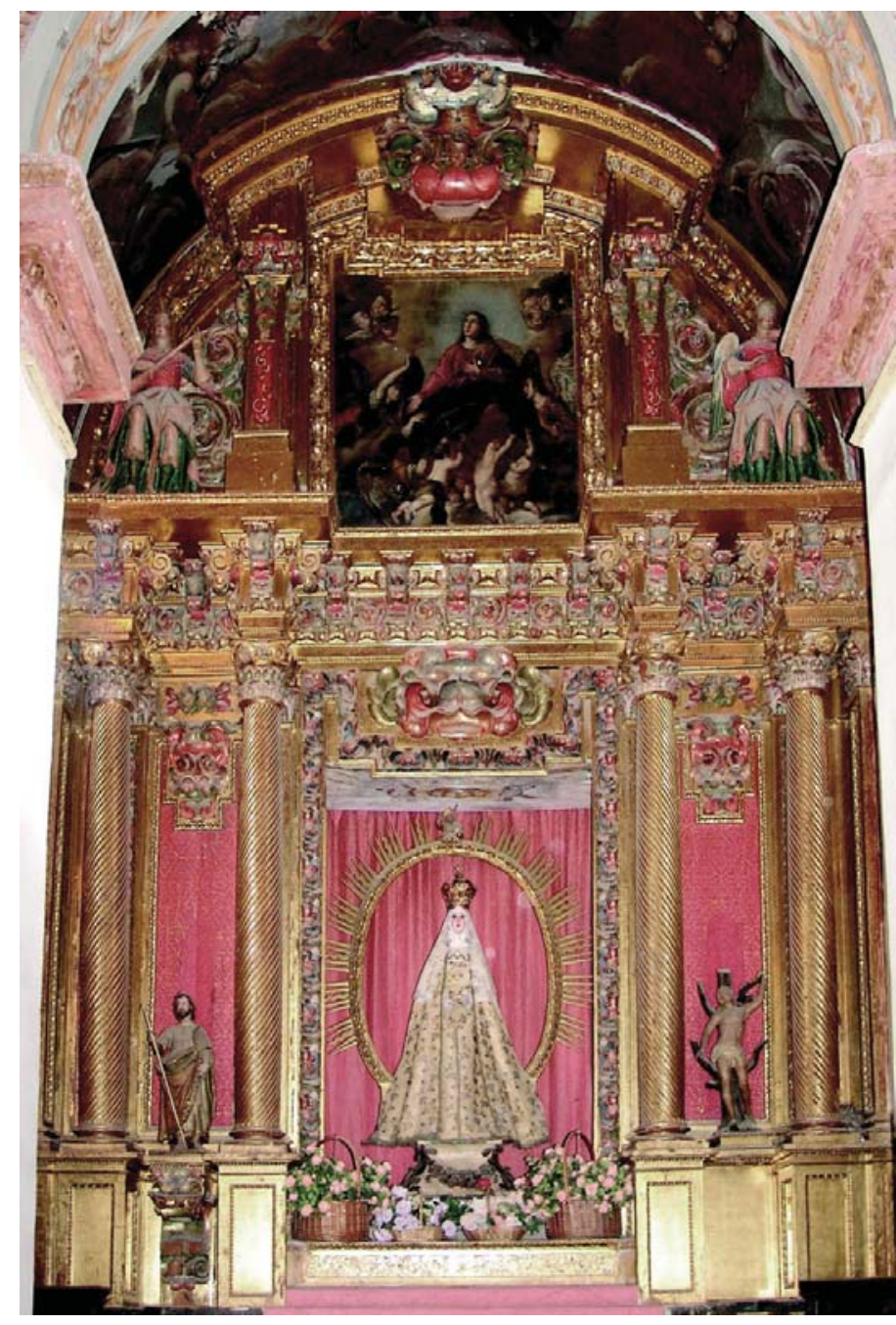

Fig. 7: Toledo. Iglesia parroquial de San Lucas. Capilla de Ntra. Sra. de la Esperanza. Retablo principal, de Juan Gómez Lobo.

y un colorido que reviste los elementos tallados y las superficies pintadas (Fig. 7). Ocupa el ámbito del fondo plano de la capilla bajo bóveda de cañón y se configura como retablo camarín. Sobre zócalo de madera con sus cuatro pedestales imitados mármoles en verde y rojo que se corresponden con los del banco del retablo, de netos cajeados y lisos sobre los que se alzan las cuatro esbeltas columnas que articulan el cuerpo principal, exentas y entorchadas, de capiteles compuestos y grandes volutas, y presentadas por sus correspondientes traspilastras, inclusas las perpendiculares de los muros laterales haciendo ángulo. Componen así una calle central más ancha para la hornacina adintelada donde está entronizada la Virgen de la Esperanza, con marco tallado de hojarasca policromada acodillado arriba y montado por ostentosa tarjeta carnosa. Los intercolumnios, más estrechos, se prestan para sendas esculturas fuera de hornacina y delante de los entrepaños sobre peanas sostenidas por ménsulas ricamente labradas que apoyan en el pedestal del retablo (con viejas tallas pequeñas de San José y San Sebastián que no acompañan) y se rebordean con marco tallado y acodillado que corona en tarja superada por una sarta de frutas, los llamados "cartones y fruteros" en el documento de dorado. El entablamento es lo más elaborado sin duda, 

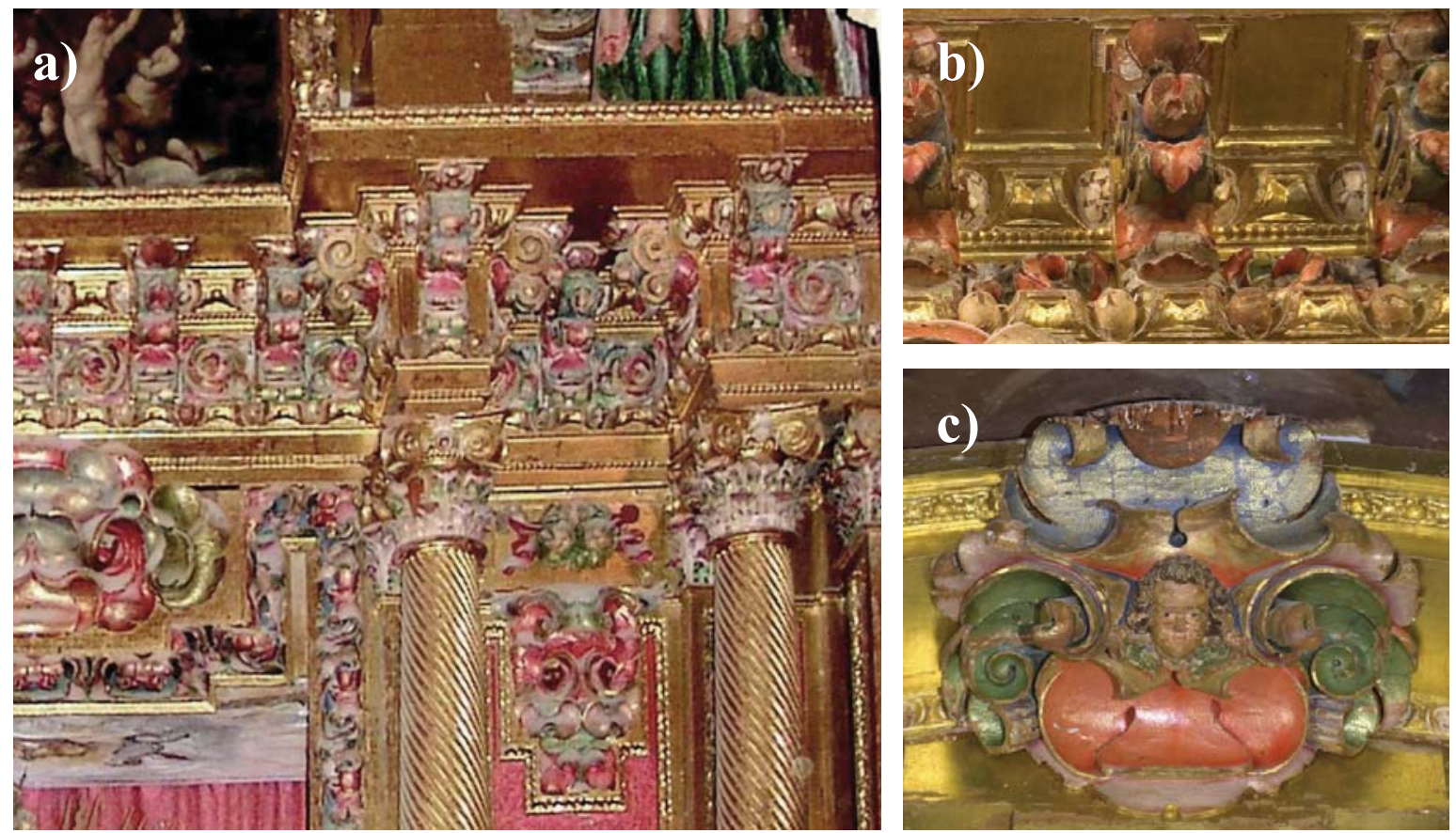

Fig. 8: Toledo. Iglesia parroquial de San Lucas. Capilla de Ntra. Sra. de la Esperanza.

Detalles del retablo principal: a) parte central, b) modillón, c) tarjeta de coronamiento.

por la profusa decoración del friso, desarrollando entre dos molduras pronunciadas de ovas y dardos, los mencionados "guebos", sus cartelas o modillones de perfil en doble voluta, con hojas y granada de adorno, y en las metopas golpes de cogollos. Retablo que también resulta interesante por el movimiento de avance sobre los capiteles de los soportes y de retranqueo en las calles, coronado por una potente cornisa que marca el paso a un ático bien construido sobre machones en cuyas tres caras se tallan hojas y frutos colgantes, los nombrados "tarjones y frutas", y se pintan subientes, cerrando en potente cerchón curvo abrochado por un tarjón o tarjeta cactiforme entre cuyas hojas destaca la cabeza de un querubín (Fig. 8). En los lunetos laterales se tallan cogollos o roleos a los que se anteponen dos figuras de ángeles músicos de pie (si acaso se sustituyeron las Virtudes declaradas en el contrato de dorado) guardando la pintura central de la Asunción de María, abigarrada composición dentro de marco tallado. Tenemos pues un retablo que afirma su carácter barroco destacando la estructura unitaria y la riqueza del lenguaje ornamental de nuevo cuño que brota en repisas, tarjetas, roleos, modillones, fruteros y molduras. Al unísono con el programa iconográfico del retablo está el decorado pictórico de la propia capilla, culminado por los pintores Simón Vicente y Nicolás de Latras ${ }^{29}$, ornando el camarín con algunas historias de la Virgen, la bóveda de lunetos con una Glorificación de la Virgen, las pechinas con los cuatro Evangelistas y la cúpula central, donde se simula un tambor abierto a modo de templete sostenido por ocho columnas salomónicas trabadas por una balaustrada y sujetando arriba una pequeña cúpula, todo lo cual constituye de por sí un buen ejemplo de integración decorativa barroca digno de mejor conservación en todo su conjunto.

29 REVENGA DOMÍNGUEZ (2003) pp. 302-303. 


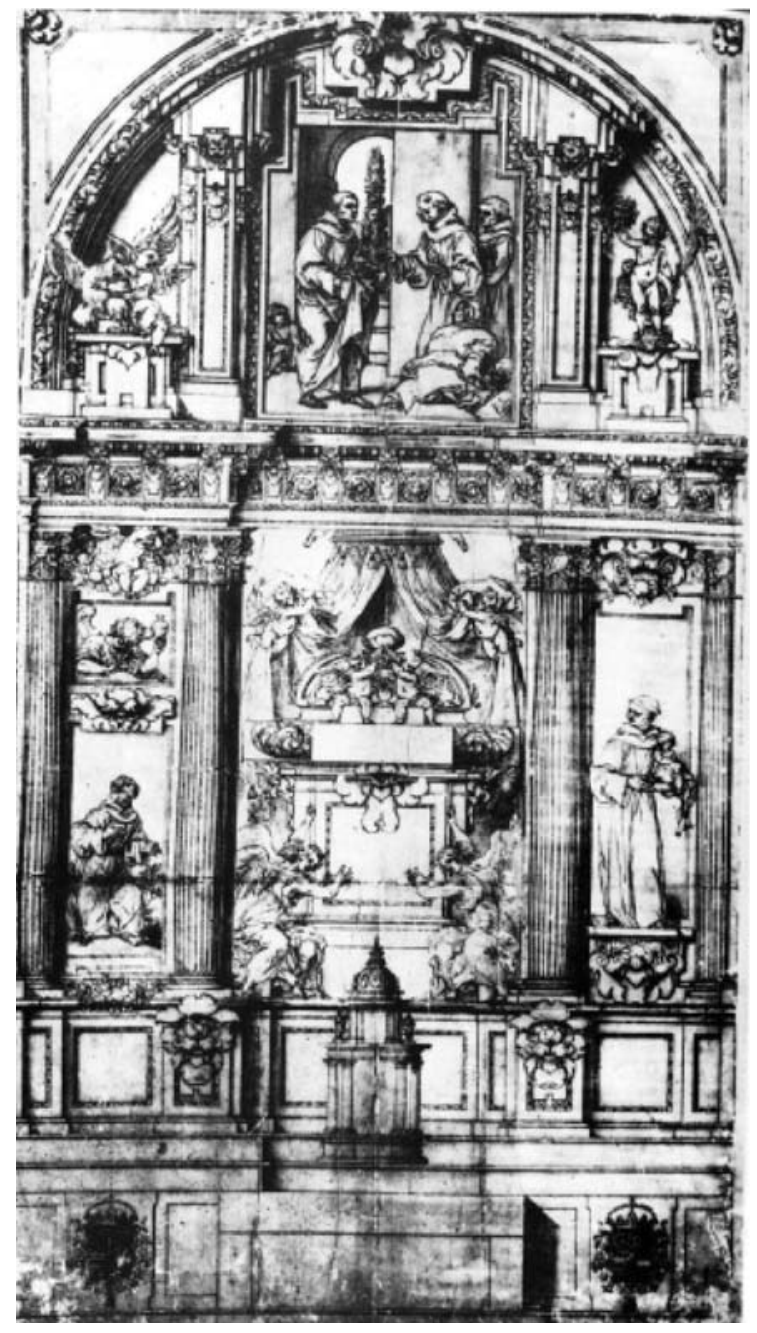

Fig. 9: Traza para el retablo mayor de la capilla de San Diego de Alcalá del convento de Santa María de Jesús de Alcalá de Henares (colección particular, Florencia).

Con estos valores compositivos y plásticos, el retablo de la capilla de Ntra. Sra. de la Esperanza de San Lucas supone un hito dentro de la retablística toledana pues nos remite a proyectos prototípicos en el ámbito madrileño y bien considerados en su misma condición de paradigmas barrocos. Nos estamos refiriendo al proyecto de retablo mayor para la iglesia parroquial de San Andrés en Madrid, del granadino Alonso Cano y datado con mayor precisión hacia $1657-1658{ }^{30}$, que a tenor del dibujo conservado en el Museo del Prado presenta el modelo ideal al que sin ambages se aproxima el retablo toledano, en su escala más reducida y tomando únicamente el cuerpo de columnas y ático. Además, un segundo paralelismo hace de este retablo toledano un reflejo casi idéntico de un dibujo preparatorio de 1657 del retablo mayor para la capilla sepulcral de San Diego de Alcalá en el convento franciscano de Santa María de Jesús en Alcalá de Henares (Madrid), dibujo de colección particular florentina dado a conocer por Pérez Sánchez, que se ha venido atribuyendo a Alonso Cano mientras que su ejecución se sabía recaída en manos del ensamblador madrileño Se-

30 RODRÍGUEZ REBOLLO (2008) p. 453. 
bastián de Benavente ${ }^{31}$, a quien definitivamente hay que considerar como su autor puesto que se trataría de la propia traza a la que se sujeta su contrato de obra de abril de $1658^{32}$ (Fig. 9). La simple comparación entre la mitad derecha de este dibujo, y el alzado que presenta el retablo de Ntra. Sra. de la Esperanza de Gómez Lobo no deja de sorprender por las muchas analogías, ya sea la propia idea constructiva como la colocación exacta de algunos elementos del adorno. Sea cual sea la vía por la que este diseño barroco anterior a 1660 fuera conocido por Juan Gómez Lobo no hace más que demostrar la viva inquietud de un artista abocado a la búsqueda de principios válidos para una renovación en la concepción del retablo toledano y cuyo taller regirá con plena autonomía artística el espacio temporal de las dos décadas siguientes con realizaciones de empeño ${ }^{33}$.

Ciertamente, los códigos barrocos se integran en la retablística toledana abriendo una etapa en la década de los sesenta en la que nuevos ejemplos se suceden en la capital como el significativo retablo de San Francisco de Borja (originalmente para la capilla de Santiago de la catedral y hoy presidiendo la capilla del Seminario Menor) cuya tipología se maneja con mayor preciosismo, en razón de su patrocinador el arzobispo Moscoso y Sandoval y debido esta vez al diseño del acreditado tracista y marmolista toledano Bartolomé Zumbigo y Salcedo, que le avala en su condición de artista versátil de clara vocación barroca ${ }^{34}$, aunque su labra en madera la realizara en 1665 un prolífico Juan Gómez Lobo, cumpliendo con que "toda la talla a de yr muy bien hecha fresca y calada y de la mesma forma que la traza demuestra" y el estofado "de las colores que pida la talla y frutos y oxas y las figuras encarnadas todo bien ymitado al natural" ${ }^{35}$. Bien proporcionado, se presenta como un retablo plano de laterales

31 RODRÍGUEZ G. DE CEBALLOS (1999) p. 264.

32 CRUZ YÁBAR (2008) pp. 379-394.

33 Algunos trabajos van ampliando el conocimiento sobre realizaciones de este importante artista barroco y cito REVENGA DOMINGUEZ, P., "Precisiones documentales sobre el retablo mayor de la iglesia parroquial de Navalcarnero", Anales de Historia del Arte, 1998, n 8, pp. 245-256; IDEM, "El arquitecto ensamblador Juan Gómez Lobo: sus obras en Los Yébenes", Anales Toledanos, XXXV, 1998, pp. 179-198; DIAZ FERNANDEZ, A. J.: "Una obra toledana en Jaén: el retablo mayor de la iglesia parroquial de Villacarrillo (1670)", Boletín Instituto de Estudios Giennenses, XLVII, no 178, 2001, pp. 231-242; últimamente, NICOLAU CASTRO, J., DIAZ FERNANDEZ, A. J.: "El retablo de Ntra. Sra. de la Soledad de la iglesia de San Miguel de Toledo y sus lienzos de Claudio Coello", Goya: Revista de Arte, nº 315, 2006, pp. 339-344.

34 Artista ya encargado desde 1654 del chapeado marmóreo del Ochavo o capilla de las Reliquias, según los planteos del Hermano Bautista y Pedro de la Torre, y a quien se debe la obra total de la iglesia de Capuchinas de esta ciudad, fundación personalísima del Cardenal Pascual Aragón, en la que destacan como obra excepcional en el medio toledano sus ricos retablos marmóreos, obrados ya en 1672, vid. SUÁREZ QUEVEDO (1990) p. 191 y ss.

35 ZARCO DEL VALLE (1916) p. 378. Juan GARCÍA DE SAN PEDRO y JOSÉ DE ORTEGA hicieron sendas trazas, aunque el Obrero Mayor, responsable de su realización, aceptó la presentada por Zumbigo, seguida en su contrato de 27 de junio de 1664 por el ensamblador Juan Gómez Lobo en precio de 22.000 reales, incluido su dorado y estofado, mientras toda la imaginería se habría de hacer en Madrid y otro tanto las pinturas. En su nueva ubicación, la capilla del Seminario Menor Santo Tomás de Villanueva de Toledo, el retablo se encuentra lamentablemente mutilado, desprovisto de su pedestal y de la figuración pictórica y escultórica originales que tan magnífico lo presentaban. Si restituimos su programa iconográfico anterior a 1940 se contemplaba en la caja central la imagen del santo jesuita con la calavera coronada en la mano, superada por un relieve de la Imposición de la casulla a San Ildefonso, dentro de una voluminosa tarjeta, y en las calles laterales seis pequeñas pinturas superpuestas con las figuras, en el lado izquierdo y desde abajo, de San José, San Ignacio y San Ildefonso; en el lado derecho, desde abajo, San Antonio de Padua, San Francisco Javier y Santa Leocadia; el ático entre contrafuertes se reservaba para una pequeña talla de la Inmaculada, 
igualmente ornados, que ofrece como particularidad compositiva el estar conformado por un cuerpo de cuatro pilastras cajeadas y enriquecido con una elegante y rítmica disposición de típicos motivos de fina talla: colgantes de frutas en los cajeados, guirnaldas en los capiteles casi jónicos, florones y cartelas geométricas en el friso bajo moldura taqueada, pequeñas tarjas en los largueros de separación de las pinturas y tarjetas de mayor tamaño en el eje de coronación de los dos cuerpos, corona de frutos que rodea el medio relieve, más otros sutiles detalles en perfiles, molduras y enjutas del medio punto y guarniciones del ático que lo decoran con gran sentido naturalista realzado por el brillante dorado y la policromía de sus piezas de adorno (Fig. 10). En estas circunstancias y con la misma afirmación en los formalismos barrocos está igualmente el poco convencional retablo de la capilla de Ntra. Sra. de la Soledad de la iglesia de San Miguel, cuyo autor es, una vez más, Juan Gómez Lobo, que lo realiza hacia 1666, y que se reduce realmente a un grandioso cuerpo entre machones cajeados y frontón curvo a modo de ático de retablo flanqueado por cuatro hermosas pinturas de Claudio Coello de desigual formato, enmarcadas y acopladas en los laterales del medio punto del testero y prescindiendo, por tanto, del resto del retablo en sí, con lo que se configura exclusivamente como una grandiosa portada en cuya hornacina de medio punto se coloca la imagen de vestir de la titular ${ }^{36}$. El léxico decorativo vuelve a ser aquí el relacionado con Pedro de la Torre, Herrera Barnuevo, Benavente y otros retablistas madrileños, donde no faltan las características tarjetas, una menor en la clave de la hornacina y otra de mayor volumen en el coronamiento, en la que descuella particularmente una cabeza de querubín, todo aderezado con la preciosa policromía colorista de la talla sobre el dorado.

Por estos mismos años el retablo de factura toledana convive en la ciudad con el foráneo, atendiendo a una obra relevante como es el retablo mayor de la conventual de las Benitas de la Concepción, planteado y obrado por el madrileño Alonso García en Toledo entre 1665 y 1666, presentando el habitual programa decorativo barroco supeditado esta vez a una composición escultórica en torno a la imagen central de la Inmaculada, y anteponiendo al esquema arquitectónico dos columnas salomónicas ${ }^{37}$, invitando con ello a los retablistas locales a la revisión de nuevos tratamientos formales. Pero el artista toledano es igual de competente para intervenir en obras fuera de la ciudad tal es el caso de la ejecución del retablo mayor de la iglesia de Navalcarnero (Madrid) por Juan Gómez Lobo, quien tras adjudicarse la obra en 1666 comprometido a seguir las trazas de Juan de Lobera era autorizado a acometer el replanteo del retablo, formalizando en enero de 1667 la escritura de obra de adaptación al ábside pese al rechazo de su autor madrileño ${ }^{38}$. En cualquier caso, la actividad arquitectónica de carácter decorativo crece en esta década afectando también a la renovación de tipologías no propiamente retablísticas como el caso del túmulo por

donación devocional del Cardenal, y a ambos lados las esculturas de San Benito y San Bernardo a plomo, vid. PALAZUELOS (1890) I p. 244.

36 Nicolau Castro, Díaz Fernández (2006) pp. 216-220.

37 AGULLÓ y COBO (1973) pp. 397-398. Atribución de las esculturas a Manuel Pereira, vid. NICOLAU CASTRO (1997) pp. 443-448. Serían las primeras columnas salomónicas dentro de un retablo que se vieron en la ciudad de Toledo, vid. DÍAZ FERNANDEZ (2004) p. 165.

38 REVENGA DOMÍNGUEZ (1998) p. 254. 


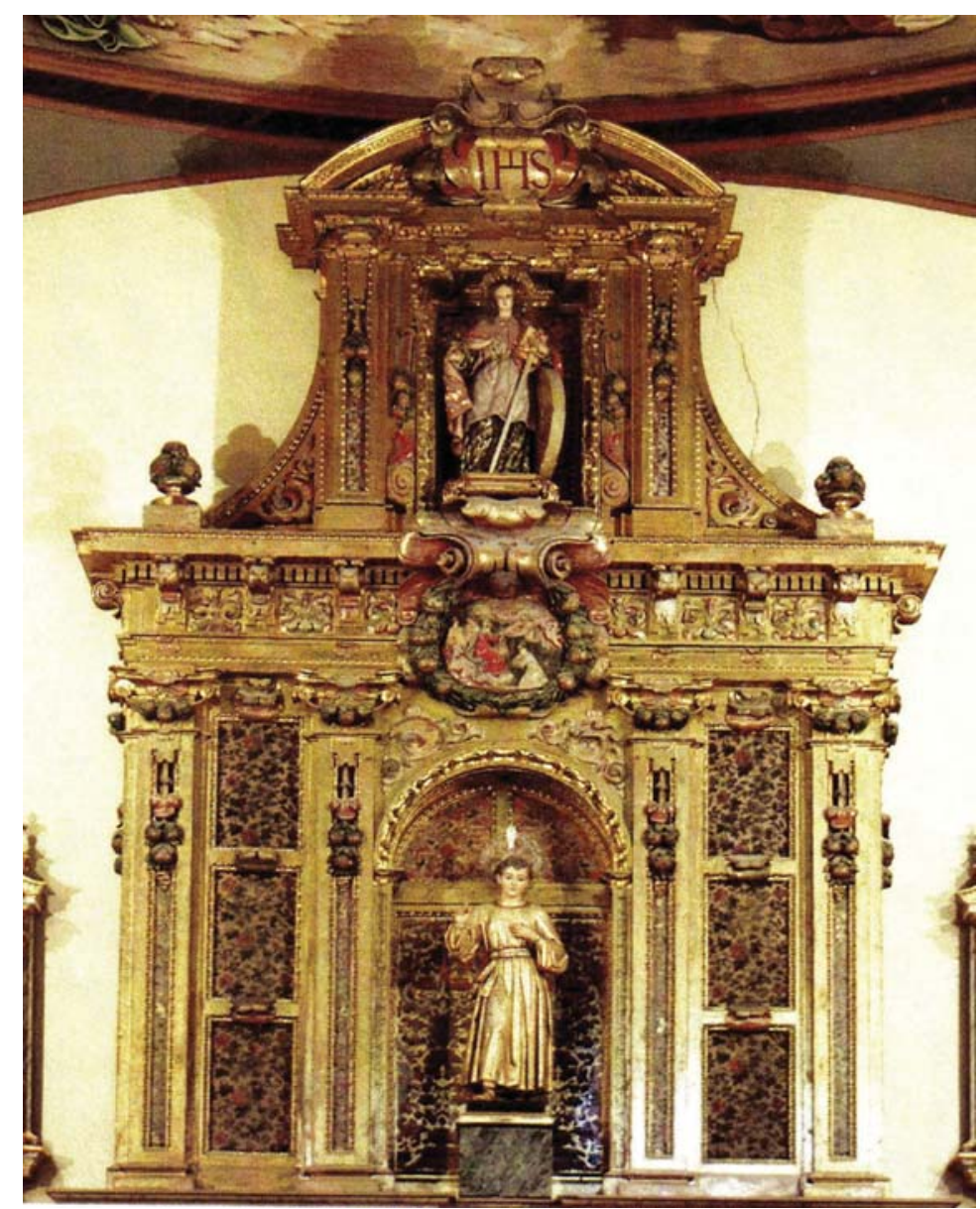

Fig. 10: Toledo. Seminario Menor "Santo Tomás de Villanueva".

Retablo principal, de Bartolomé Sombigo y Juan Gómez Lobo.

las exequias de Felipe IV, obra efímera trazada y alzada en la catedral por el maestro de arquitectura Juan Muñoz de Villegas con los pintores Nicolás de Latras y Diego Rodríguez Romano para el 21 de diciembre de $1665^{39}$, que por ser obra anterior quizás no se mostrara en el nivel de novedad estética que debió aportar años después el gran monumento de Jueves Santo que los pintores Francisco Rizi y Claudio Coello proyectaron y realizaron entre 1668 y 1669 para su uso anual en las celebraciones de la catedral a instancias del Cardenal Aragón ${ }^{40}$ y que hubo de tomarse como modelo obligado en creaciones similares alzadas por los talleres locales.

En definitva, a la vista de una serie de retablos toledanos apenas conocidos, se hace factible situar el fructífero proceso de encuentro de los artistas toledanos con la corriente barroca madrileña a lo largo de la década de los años sesenta del siglo XVII con piezas retablísticas bien definidas en las que se adoptan plenamente los esquemas compositivos de unidad estructural y las figuras propias del lenguaje decorativo preconizado por Alonso Cano en el ámbito madrileño aunque difundido principalmente por Pedro de la Torre, en tanto la gran capacidad de interacción de la escuela madrileña en los centros artísticos más cercanos como la ciudad de Toledo, donde la

39 REVENGA DOMÍNGUEZ (2001) pp. 165-182.

40 NICOLAU CASTRO (1989) pp. 216-220. 
conexión con las fórmulas barrocas de origen es esencial en la evolución del retablo toledano, identificada con el estilo del arquitecto y ensamblador Juan Gómez Lobo quien lo patentiza en una de sus primeras realizaciones como es el modélico retablo principal de la capilla de Ntra. Sra. de la Esperanza de San Lucas; una intervención de hacia 1660 que profundiza en la nueva estética barroca focalizada en obras catedralicias que, sin duda, ejercen como factor de cambio en otras tantas actuaciones retablísticas dentro de la ciudad, que aunque bien documentadas no han perdurado en el tiempo.

\section{Bibliografía}

Agulló y Cobo, Mercedes, «Tres arquitectos de retablos del siglo XVII: Sebastián de Benavente, José de la Torre y Alonso García», AEA, XLVI, nº 184, 1973, pp. 391-399.

Ainaud de Lasarte, Joan, Toledo, Barcelona, 1947.

Cruz YÁBAR, Juan María, "Sebastián de Benavente y la capilla de San Diego de Alcalá", $A E A$, LXXXI, no 324, 2008, pp. 379-394.

Díaz Fernández, Antonio J., "Origen y presencia de la columna salomónica en el retablo barroco toledano" Toletum, no 49, 2004, pp. 143-190.

Díaz Fernández,, A. J., "Sobre el retablo mayor de la ermita de Nuestra Señora de la Poveda de Villa del Prado (Madrid) y sus autores toledanos José y Alonso de Ortega (1655)", AIEM, XLV, 2005, pp. 179-207.

Díaz García, Abraham, Sebastián de Herrera Barnuevo (1619-1671). Obra pictóri$c a$, Cuadernos de Arte e Iconografía, Madrid, XIX, nº 37, $1^{\circ}$ semestre 2010.

Fernández Collado, Ángel, Rodríguez González, Alfredo, Castañeda Tordera, Isidoro: Los diseños de la catedral de Toledo, Toledo, 2009.

Inventario. Inventario Artístico de Toledo Capital, tomo I, DGBBAA, Madrid, 1983

MARíAs, F., "Un retablo de Alonso Carbonell atribuido al Greco y una hipótesis sobre los de la capilla de San José", AEA, L, n 199, 1977, pp. 323-326.

Marías, F., La arquitectura del Renacimiento en Toledo (1541-1631), 4 vols. Madrid, 1983-1986.

MARíAs, F.,, "Alonso Cano y la columna salomónica”, en Figuras e imágenes del Barroco. Estudios sobre el barroco español y sobre la obra de Alonso Cano, Madrid, 1999, pp. 291-322.

Nicolau Castro, Juan, "Precisiones documentales sobre el monumento barroco de la catedral de Toledo y un dibujo madrileño del último tercio del siglo XVII", $A E A$, LXII, n² 246, 1989, pp. 216-219.

Nicolau Castro, J., «La maqueta del trono de la Virgen de Sagrario de la Catedral de Toledo", Academia: Boletín de la Real Academia de Bellas Artes de San Fernando, $\mathrm{n}^{\mathrm{o}} 83,1996$, pp. 271-286. 
Nicolau Castro, J., «Nuevas obras de Manuel Pereira localizadas en Toledo», $A E A$, LXX, n 280, 1997, pp. 443-448.

Nicolau Castro, J., Díaz Fernández, A. J., "El retablo de Ntra. Sra. de la Soledad de la iglesia de San Miguel de Toledo y sus lienzos de Claudio Coello", Goya: Revista de Arte, $\mathrm{n}^{\circ} 315,2006$, pp. 339-344.

Palazuelos, Conde de Cedillo, lópez de Ayala-Alvarez de Toledo, Vizconde de, Toledo: Guía artístico-práctica de Toledo, 2 vols. Toledo, 1984 (ed. facs. Toledo 1890).

Pérez Sedano, F., Datos documentales para la Historia del Arte Español. I Notas del Archivo de la Catedral de Toledo, Madrid, 1914.

Ramírez De Arellano, R., Las Parroquias de Toledo, Toledo, 1921.

Revenga Domínguez, Paula, "Precisiones documentales sobre el retablo mayor de la iglesia parroquial de Navalcarnero", Anales de Historia del Arte, 1998, nº 8, pp. 245-256.

Revenga Domínguez, P., "Pyra Philipica. El túmulo erigido en la Ciudad Imperial para las exequias de Felipe IV", Cuadernos de Arte e Iconografía, t. 10, n 19, 2001, pp. 165-182. Revenga Domínguez (2002)

Revenga Domínguez, Paula, Pintura y Sociedad en el Toledo Barroco, Toledo, 2002.

Rodríguez G. De Ceballos, A., "Alonso Cano y el retablo", en Figuras e imágenes del Barroco. Estudios sobre el barroco español y sobre la obra de Alonso Cano, Madrid, 1999, pp. 251-269.

Rodríguez Rebollo, Ángel, "A propósito de Alonso Cano: el dibujo para el retablo de San Diego de Alcalá y su homónimo para San Andrés" en In Sapientia Libertas: Escritos en homenaje al profesor Alfonso E. Pérez Sánchez, Madrid-Sevilla, 2008, pp. 452-458.

SuÁrez Quevedo, Diego, Arquitectura barroca en Toledo: s. XVII, Toledo, 1990.

Tovar Martín, Virginia, «El arquitecto ensamblador Pedro de la Torre», AEA, XLVI, $\mathrm{n}^{\circ} 183,1973$, pp. 261-298.

Zarco del Valle, Manuel R., Datos documentales para la Historia del Arte español. II Documentos de la Catedral de Toledo, Madrid, 1916. 